\title{
UJI AKTIVITAS ANALGESIK ASAM 2-(3-(KLOROMETIL)BENZOILOKSI)BENZOAT DAN ASAM 2-(4-(KLOROMETIL)BENZOILOKSI)BENZOAT PADA TIKUS WISTAR JANTAN DENGAN METODE PLANTAR TEST
}

\author{
Wahyu Dewi Tamayanti, Ratna Megawati Widharna, Caroline*), Bambang Soekarjo
}

Fakultas Farmasi, Universitas Katolik Widya Mandala, Surabaya, Indonesia

Received April 11, 2016; Accepted April 26, 2016

\begin{abstract}
The new compounds of salicylic acid derivatives, 2- (3- (chloromethyl) benzoyloxy) benzoic acid and 2- (4- (chloromethyl) benzoyloxy) benzoic acid were synthesized to generate better analgesic activity and lesser stomach irritation of salicylic acid. The 2- (4- (chloromethyl) benzoyloxy) benzoic acid and 2(3- (chloromethyl) benzoiloksi) benzoic acid were synthesized by Schotten-Baumann acylation process. In this study, analgesic activity was tested by plantar test method. The compounds were administered to the tested animals at 12.5; 25; 50; 100; and $200 \mathrm{mg} / \mathrm{kg} \mathrm{BW}$ of doses. Analgesic activity was determined by the response time of rat to pain induced by infra red. The percentage of pain hindrance was calculated from the mean of response time to pain. Pain hindrance percentage were shown as: $74.28 \%$; 105.58\%; $110.58 \%$; 115.29\%; and 175.87\% after administration of 2- (4- (chloromethyl) benzoyloxy) benzoic acid at doses of 12.5; 25; 50; 100; and $200 \mathrm{mg} / \mathrm{kg}$. The pain hindrance percentage after administration of 2- (3(chloromethyl) benzoyloxy) benzoaic acid, were 85.30\%; 92.48\%; 124.96\%; 180.36\%; and 208.01\% respective to the doses of 12.5; 25; 50; 100; and $200 \mathrm{mg} / \mathrm{kg}$. Five doses of acetyl salicylic acid ranged from $12.5 \mathrm{mg} / \mathrm{kg}$ to $200 \mathrm{mg} / \mathrm{kg}$ showed pain hindrance percentage as: 26\%; 34.34\%; 45.68\%; 60.38\%; and $114.12 \%$. This study indicated that 2- (3- (chloromethyl) benzoyloxy) benzoic acid and 2- (4(chloromethyl) benzoyloxy) benzoic acid generated higher analgesic activity than acetyl salicylic acid.
\end{abstract}

Keywords : analgesic activity, plantar test, 2- (3- (chloromethyl) benzoyloxy) benzoic acid, 2-(4(chloromethyl) benzoyloxy) benzoic acid

\section{PENDAHULUAN}

Asam asetilsalisilat bekerja sebagai analgesik antipiretik dengan menghambat prostaglandin yang dibentuk dari metabolisme asam arakidonat dengan katalisator enzim siklooksigenase (Furst dan Munster,2002). Asam asetilsalisilat memiliki efek samping, diantaranya terhadap pernafasan dan saluran cerna yang dapat menyebabkan perdarahan lambung berat (Gunawan, 2009). Alternatif untuk meningkatkan aktivitas analgesik-antipiretik asam asetilsalisilat serta menurunkan efek samping terus diupayakan. Modifikasi struktur dari senyawa turunan asam salisilat dilakukan dengan mengubah gugus karboksil melalui pembentukan garam, ester, atau amida; modifikasi pada gugus karboksil dan hidroksil; substitusi pada gugus hidroksil; memasukkan gugus hidroksil atau gugus yang lain pada cincin aromatik atau dengan mengubah gugus fungsional (Purwanto dan Susilowati, 2000).

Pratiwi (2009) telah melakukan modifikasi struktur dengan penambahan gugus 3klorometilbenzoil klorida, menghasilkan senyawa asam 3-klorometilbenzoil salisilat atau disebut juga asam 2-(3-(klorometil)benzoiloksi)benzoate yang aktivitas analgesiknya telah diujikan pada mencit dengan menggunakan metode writhing test. Hasil uji aktivitas analgesik asam 2-(3(klorometil)benzoiloksi) benzoat menunjukkan harga Effective Dose 50 (ED) 50 sebesar 14,05 $\mathrm{mg} / \mathrm{kgBB}$ dimana hasil tersebut lebih kecil dibandingkan dengan $\mathrm{ED}_{50}$ dari asam asetilsalisilat yaitu sebesar 20,83 $\mathrm{mg} / \mathrm{kgBB}$. Hal ini menunjukkan bahwa senyawa asam 2-(3(klorometil)benzoiloksi)benzoat lebih aktif dan 
potensial sebagai analgesik dibandingkan asam asetilsalisilat.

Modifikasi lain dilakukan pada asam salisilat dengan mereaksikan dengan asam 4klorometilbenzoil klorida melalui reaksi asilasi Schotten-Baumann menghasilkan asam 2-(4(klorometil)benzoiloksi)benzoat. Secara teoritis, asam 2-(4-(klorometil)benzoiloksi)benzoat memiliki nilai $\log \mathrm{P}$ sebesar 3,73, lebih tinggi dari $\log \mathrm{P}$ asam asetilsalisilat yaitu 1,2. Hal ini mengindikasikan bahwa asam 2-(4-(klorometil) benzoiloksi)benzoat mempunyai sifat lipofilik lebih besar dibandingkan asam asetilsalisilat. Martak dkk. (2009) melakukan uji aktivitas analgesik asam 2-(4(klorometil)benzoiloksi)benzoat terhadap mencit dengan menggunakan metode writhing test dan menunjukkan bahwa nilai $\mathrm{ED}_{50}$ asam 2-(4(klorometil)benzoiloksi)benzoat sebesar 11,31 $\mathrm{mg} / \mathrm{kg} \quad \mathrm{BB}$, sedangkan harga $\mathrm{ED}_{50}$ asam asetilsalisilat adalah $20,83 \mathrm{mg} / \mathrm{kg} \mathrm{BB}$.

Natalia dkk. (2013) memodelkan beberapa turunan senyawa asam asetilsalisilat yang berinteraksi dengan reseptor siklooksigenase-2 menggunakan program Glide (lisensi Schrodinger). Dari hasil penelitian tersebut menunjukkan nilai Glide Score (GScore) senyawa asam 2-(3(klorometil)benzoiloksi)benzoat sebesar $-9,48$ dan asam 2-(4-(klorometil)benzoiloksi)benzoate sebesar -7,39. Nilai tersebut lebih rendah dibandingkan dengan senyawa analgesik paten lain yang sudah beredar seperti asam asetilsalisilat (GScore $-5,88$ ) dan celecoxib (GScore -9,47). Nilai GScore merupakan sistem penilaian empiris yang mendekati energi bebas pengikatan ligan dan digunakan untuk menentukan peringkat pose ligan yang berbeda. Semakin kecil nilai GScore maka semakin stabil ikatan obat dan reseptor yang terbentuk (Natalia dkk, 2013). Stabilnya obat dengan reseptor tersebut akan menghasilkan efek farmakologi yang lebih baik.

Tingkat keamanan asam 2-(3(klorometil)benzoiloksi) benzoat dan 2-(4(klorometil)benzoiloksi) benzoat diteliti dengan dilakukannya uji toksisitas akut untuk mengetahui efek samping penggunaan senyawa asam 2-(3(klorometil)benzoiloksi)benzoat pada mencit. Dari uji toksisitas akut, kedua senyawa menunjukkan nilai Lethal Dose 50 (LD50) sebesar 2000 mg/kg BB
(Soekardjo et al., 2011) Penelitian mengenai aktivitas analgesik kedua senyawa sintetis masih terus dilakukan sebagai upaya untuk melengkapi data aktivitas dan keamanannya. Pada penelitian ini dilakukan penelitian uji aktivitas analgesik pada tikus Wistar jantan untuk membuktikan reprodusibilitas aktivitas senyawa pada rodensia dan membuktikan pengaruh aktivitas analgesik senyawa pada susunan saraf pusat dengan menggunakan metode Plantar Test.

\section{METODE PENELITIAN}

Bahan yang digunakan dalam penelitian antara lain asam salisilat pharmaceutical grade (p.g.) (PT Brataco), asam 3(klorometilbenzoil)klorida pro analysis (p.a.) (Sigma Aldrich), asam 4(klorometilbenzoil)klorida p.a. (Sigma Aldrich), aseton p.a (Mallindcroft), etanol p.a. (Mallindcroft), piridin p.a. (Mallindcroft), water for injection, PGA p.g. (PT Brataco), etil asetat p.a. (Merck), n-heksan (Merck) dan aquadestilata.

Alat yang digunakan dalam penelitian ini antara lain seperangkat alat refluks, Electrothermal Melting Point Apparatus, bejana KLT lempeng silika gel 60 F254, oven, spektrofotometer FT-IR Jasco FT/IR-5300, disposable syringe, timbangan analitis, kertas saring whatman, Basile Plantar Test dan alat-alat gelas yang biasa digunakan dalam laboratorium.

Pada penelitian ini digunakan tikus Wistar jantan sehat dan belum pernah digunakan untuk percobaan lain, tidak ada kelainan pada bagian tubuh, dengan usia 2 - 3 bulan, bobot 150 - $250 \mathrm{~g}$. Sebelumnya tikus diaklimatisasi selama tujuh hari. Sebelum digunakan untuk penelitian, hewan coba dipuasakan 18 jam tetapi tetap diberi minum.

\section{Sintesis senyawa turunan asam salisilat}

Sintesis senyawa dilakukan dengan menggunakan metode Schotten Baumann. Senyawa 2-(3-(klorometil)benzoiloksi) benzoat dibuat dengan cara melarutkan asam salisilat (0,025 mmol) dalam aseton dan ditambahkan piridin. Disisi lain, senyawa asam 3klorometilbenzoil klorida $(0.025 \mathrm{mmol})$ dilarutkan dalam aseton. Selanjutnya, larutan asam 3klorometilbenzoil klorida diberikan tetes demi 
tetes ke dalam larutan asam salisilat. Campuran direfluks pada suhu $\pm 56^{\circ} \mathrm{C}$ selama 4 jam. Setelah dingin, campuran ditambah air suling perlahanlahan sampai terbentuk endapan. Endapan disaring dan direkristalisasi dengan alkohol 60\%. Kristal 2(3-(klorometil)benzoiloksi)benzoat yang terbentuk dikeringkan.

Senyawa 2-(4-(klorometil)benzoiloksi) benzoat dibuat dengan cara melarutkan asam salisilat $(0,025$ mmol) dalam aseton dan ditambahkan piridin. Disisi lain, senyawa 4-klorometilbenzoil klorida (0,025 mmol) dilarutkan dalam aseton. Selanjutnya, larutan asam 4-klorometilbenzoil klorida diberikan tetes demi tetes ke dalam larutan asam salisilat. Campuran direfluks pada suhu $\pm 56^{\circ} \mathrm{C}$ selama 4 jam. Setelah dingin, campuran ditambah air suling perlahan-lahan sampai terbentuk endapan. Endapan disaring dan direkristalisasi dengan alkohol $60 \%$. Kristal 2-(4-(klorometil)benzoiloksi) benzoat yang terbentuk dikeringkan.

Senyawa hasil sintesis diuji kualitatif yaitu dilakukan pengamatan secara organoleptis meliputi bentuk, bau, dan warna. Pada masing-masing senyawa yang terbentuk dilakukan uji kemurnian dengan uji titik leleh dan uji Kromatografi Lapis Tipis, serta uji identifikasi struktur dengan spektrofotometer inframerah. Pemeriksaan titik leleh dilakukan tiga kali replikasi dengan menggunakan Electrothermal Melting Point Apparatus. Pemeriksaan Kromatografi Lapis Tipis dilakukan dengan menotolkan senyawa pada fase diam silica gel F254 menggunakan tiga macam fase gerak yang memiliki tingkat kepolaran yang berbeda yaitu etil asetat : etanol $(1: 1, \mathrm{v} / \mathrm{v})$, aseton : etanol $(8: 2, \mathrm{v} / \mathrm{v})$ dan $\mathrm{n}$-heksan : etanol $(2: 8, \mathrm{v} / \mathrm{v})$ untuk pengujian pada 2-(3(klorometil)benzoiloksi)benzoate, serta etil asetat : etanol $(1: 5, \mathrm{v} / \mathrm{v})$, aseton : etanol $(9: 1, \mathrm{v} / \mathrm{v})$ dan $\mathrm{n}-$ heksan : etanol $(1: 2, \mathrm{v} / \mathrm{v})$ untuk pengujian pada 2(4-(klorometil)benzoiloksi) benzoat.

\section{Uji aktivitas analgesik senyawa turunan}

Aktivitas analgesik dilakukan dengan alat basile plantar test yang dapat menghantarkan panas pada kisaran $55-56^{\circ} \mathrm{C}$. Pada penelitian ini terdapat 7 kelompok sebagai berikut: 1 kelompok kontrol negatif, 1 kelompok kontrol positif, dan 5 kelompok uji, dengan 6 ekor tikus Wistar jantan pada masing- masing kelompok. Tikus Wistar jantan pada kelompok kontrol negatif dipapari dengan akuades, sedangkan pada kelompok kontrol positif dipapari dengan asam asetil salisilat masingmasing dengan dosis yang sesuai dengan kelompok uji. Tikus Wistar jantan telah diaklimatisasi selama 7 hari sebelum digunakan pada penelitian ini. Uji aktivitas analgesik, dilakukan pada tikus Wistar setelah akuades, senyawa pembanding (kontrol positif), dan senyawa uji dipaparkan secara oral pada dosis 12,$5 ; \quad 25 ; \quad 50 ; 100 ; \quad 200 \mathrm{mg} / \mathrm{kgBB}$. Aktivitas analgesik ditentukan dengan cara mengamati waktu respon yang ditunjukkan oleh tikus berupa diangkat atau dijilatnya kaki setelah paparan stimulus panas yang diberikan sebagai induktor nyeri (Mishra dkk., 2011). Stimulus panas menggunakan radiasi inframerah sebagai sumber panas dipaparkan pada kaki tikus dengan interval waktu 10 menit hingga mencapai 1 jam. Waktu respon terhadap paparan induktor nyeri dicatat sebelum dan sesudah pemberian analgesik (Vogel, 2008). Hasil kumulatif dari waktu respon tikus terhadap paparan panas pada tiap kelompok uji kemudian dibandingkan terhadap kelompok kontrol untuk selanjutnya dianalisis dengan one way ANOVA. Rerata waktu bertahan terhadap paparan induktor nyeri dicatat dan dihitung sebagai persentase hambatan nyeri, menggunakan persamaan berikut:

$$
\% \text { hambatan nyeri }=\left(\mathrm{f}_{\mathrm{K}}-\mathrm{f}_{\mathrm{T}}\right) / \mathrm{f}_{\mathrm{K}} \times 100 \%
$$

dimana:

$\mathrm{f}_{\mathrm{T}}=$ waktu rata-rata kemampuan untuk menahan nyeri pada kelompok uji

$\mathrm{f}_{\mathrm{K}}=$ waktu rata-rata kemampuan untuk menahan nyeri pada kelompok kontrol

\section{HASIL DAN PEMBAHASAN}

Senyawa yang digunakan dalam penelitian ini telah disintesis ulang dan ada beberapa yang telah disimpan beberapa waktu yang lalu. Karena data stabilitas masih belum ada, maka dilakukan uji kemurnian menggunakan Kromatografi Lapis Tipis (KLT) dengan berbagai macam fase gerak untuk mengetahui kemurnian dari asam 2-(3(klorometil)benzoiloksi) benzoat dan 2-(4- 
(klorometil)benzoiloksi) benzoat. Hasil uji KLT dinyatakan dengan membandingkan harga faktor retardasi (Retardation factor, $\mathrm{R}_{\mathrm{f}}$ dari senyawa asam 2-(3-(klorometil)benzoiloksi) benzoat dan 2-(4- (klorometil)benzoiloksi) benzoat yang telah disintesis dengan senyawa penyusunnya menggunakan tiga macam fase gerak yang berbeda kepolaran dan ditunjukkan pada Tabel 1 .

Tabel I. Hasil uji KLT senyawa asam 2-(3-(klorometil)benzoiloksi) benzoat dan 2-(4-(klorometil)benzoiloksi) benzoat dengan berbagai macam fase gerak

\begin{tabular}{|c|c|c|c|c|}
\hline Senyawa & Fase gerak & $\begin{array}{l}\text { Harga } R_{f} \\
\text { Asam } \\
\text { Salisilat } \\
\end{array}$ & $\begin{array}{c}\text { Harga } R_{f} \\
\text { senyawa benzoil } \\
\text { klorida }\end{array}$ & $\begin{array}{c}\text { Harga } R_{f} \text { hasil } \\
\text { senyawa yang } \\
\text { disintesis }\end{array}$ \\
\hline \multirow{3}{*}{ asam 2-(3-(klorometil)benzoiloksi) benzoat } & $\begin{array}{l}\text { etil asetat : etanol } \\
(1: 1, \mathrm{v} / \mathrm{v})\end{array}$ & 0,74 & 0,79 & 0,82 \\
\hline & $\begin{array}{c}\text { n-heksana : etanol } \\
(2: 8, \mathrm{v} / \mathrm{v})\end{array}$ & 0,70 & 0,78 & 0,88 \\
\hline & $\begin{array}{c}\text { aseton : etanol } \\
(8: 2, \mathrm{v} / \mathrm{v})\end{array}$ & 0,71 & 0,76 & 0,78 \\
\hline \multirow{3}{*}{ asam 2-(4-(klorometil)benzoiloksi) benzoat } & $\begin{array}{l}\text { aseton : etanol } \\
\qquad(9: 1, \mathrm{v} / \mathrm{v})\end{array}$ & 0,56 & 0,70 & 0,80 \\
\hline & $\begin{array}{c}\text { etil asetat : etanol } \\
\qquad(1: 5, \mathrm{v} / \mathrm{v})\end{array}$ & 0,65 & 0,68 & 0,75 \\
\hline & $\begin{array}{c}n \text {-heksana : etanol } \\
(1: 2, \mathrm{v} / \mathrm{v})\end{array}$ & 0,45 & 0,56 & 0,62 \\
\hline
\end{tabular}

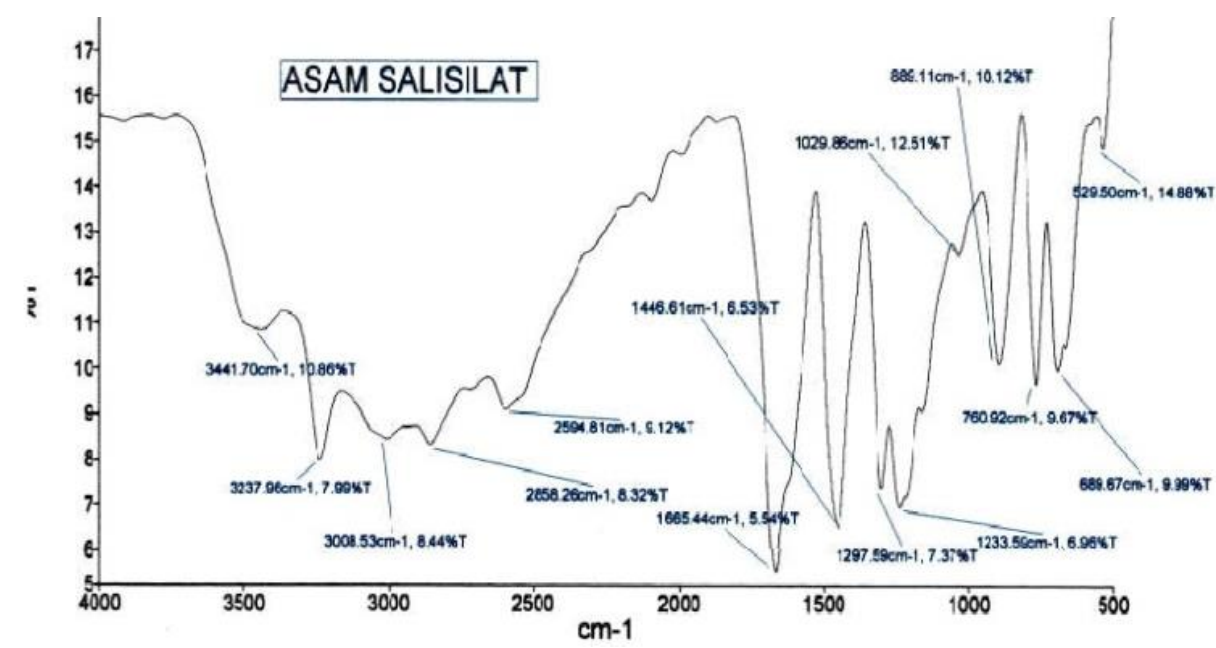

Gambar 1. Spektrum inframerah asam salisilat

Tabel 2. Karakteristik spektrum inframerah asam salisilat

\begin{tabular}{ccc}
\hline Gugus fungsi & \multicolumn{2}{c}{ Bilangan gelombang $\left(\mathrm{cm}^{-1}\right)$} \\
\cline { 2 - 3 } O-H alkohol & Asam salisilat & $3400-3650$ \\
\cline { 2 - 3 } O-H fenol & 3441,70 & $3200-3550$ \\
C=O asam & 3237,96 & $1600-1850$ \\
C=C aromatis & 1665,44 & $1300-1600$ \\
C-O asam & 1446,61 & $1100-1300$ \\
\hline
\end{tabular}

\footnotetext{
* (Robert and David, 2005; Mcmurry \& Simanek, 2007)
} 
Hasil uji kromatografi lapis tipis menunjukkan bahwa noda yang terbentuk adalah noda tunggal. Jika dilakukan pengamatan pada harga $R f$, nampak bahwa harga $R f$ asam 2-(3-(klorometil) benzoiloksi)benzoat dan asam 2-(4(klorometil)benzoiloksi)benzoat berbeda dengan harga $R f$ asam salisilat dan harga $R f$ senyawa benzoilklorida yaitu 3-klorometilbenzoil klorida dan 4-klorometilbenzoil klorida. Hal ini mengindikasikan bahwa kedua senyawa turunan sudah terbentuk dan murni secara kromatografi lapis tipis.

Untuk mengetahui kemurnian senyawa asam 2(3-(klorometil)benzoiloksi)benzoat dan asam 2-(4(klorometil)benzoiloksi)benzoat, maka dilakukan pemeriksaan titik leleh dengan menggunakan alat Melting Point Apparatus. Hasil pemeriksaan titik leleh menunjukkan bahwa pada tiga kali replikasi, senyawa asam 2-(3-(klorometil)benzoiloksi)benzoat menunjukkan rentang titik leleh $109-111^{\circ} \mathrm{C}$ dan senyawa asam 2-(4-(klorometil)benzoiloksi)benzoat menunjukkan rentang titik leleh $157-159^{\circ} \mathrm{C}$ sedangkan titik leleh asam salisilat $158-160^{\circ} \mathrm{C}$. Pada uji titik leleh didapatkan rentang titik leleh senyawa asam 2-(3-(klorometil)benzoiloksi) benzoat dan asam 2-(4-(klorometil)benzoiloksi) benzoat tidak lebih dari $2^{\circ} \mathrm{C}$ dan apabila dibandingkan dengan data titik leleh senyawa dari penelitian sebelumnya, didapat hasil pemeriksaan titik leleh yang sama, karenanya dapat dikatakan senyawa yang telah disintesis murni secara titik lebur.

Identifikasi struktur senyawa secara spektrofotometer inframerah (IR) digunakan untuk mengetahui gugus-gugus fungsi dan sidik jari pada senyawa hasil sintesis yang telah disintesis. Hasil uji identifikasi menunjukkan spektrum inframerah senyawa asam salisilat pada Gambar 1 dan karakteristik spektrum asam salisilat pada Tabel 2. Spektrum inframerah dari senyawa asam 2-(3(klorometil)benzoiloksi)benzoate ditunjukkan pada Gambar 2 dan karakteristik spektrum inframerah pada Tabel 3, sedangkan spektrum inframerah serta karakteristik asam 2-(4-(klorometil) benzoiloksi)benzoat ditunjukkan pada Gambar 3 dan Tabel 4.

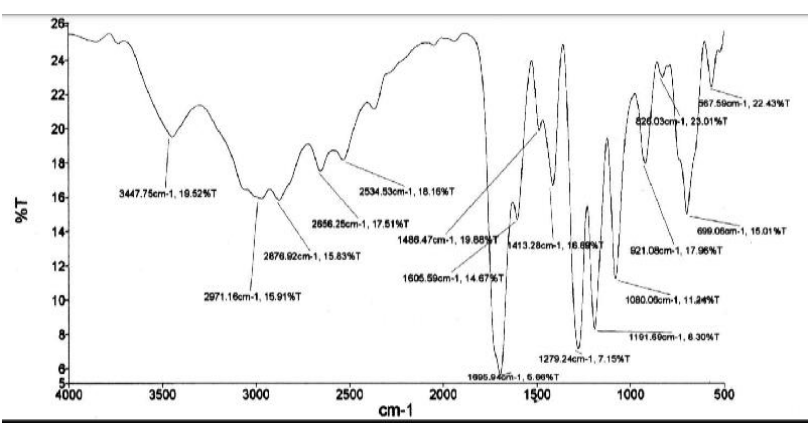

Gambar 2. Spektrum inframerah senyawa asam 2-(3-(klorometil) benzoiloksi)benzoat

Tabel 3. Karakteristik spektrum inframerah senyawa asam 2-(3-(klorometil)benzoiloksi)benzoat

\begin{tabular}{cccc}
\hline \multirow{2}{*}{ Gugus fungsi } & \multicolumn{3}{c}{ Bilangan gelombang $\left(\mathrm{cm}^{-1}\right)$} \\
\cline { 2 - 4 } & $\begin{array}{c}\text { Asam 2-(3- } \\
\text { (klorometil)benzoiloksi)benzoat }\end{array}$ & $\begin{array}{c}\text { Hasil sintesis } \\
\text { terdahulu }\end{array}$ & Pustaka* $^{*}$ \\
\hline O-H alkohol & 3447,75 & 3444,2 & $3400-3650$ \\
C=O ester & 1695,94 & 1694,7 & $1680-1760$ \\
C=C aromatis & $1486,47-1605,59$ & $1488,2-1605,6$ & $1475-1600$ \\
C-O ester & 1279,24 & 1280,3 & $1210-1320$ \\
\hline
\end{tabular}

* (Robert and David, 2005; Mcmurry \& Simanek, 2007) 


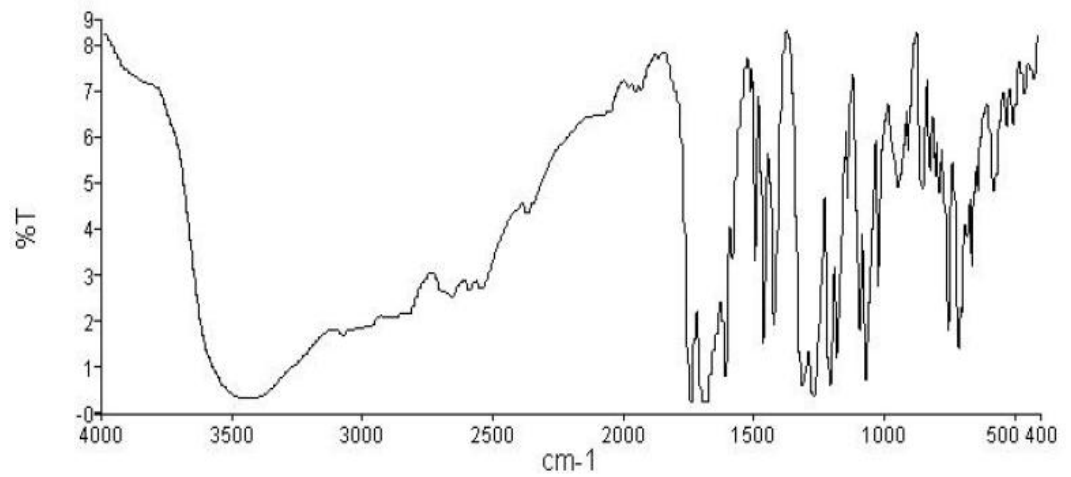

Gambar 3. Spektrum Inframerah (IR) dari asam 2-(4-(klorometil) benzoiloksi)benzoat

Tabel 4. Karakteristik Spektrum Inframerah Asam 2-(4-(klorometil)benzoiloksi)benzoat

\begin{tabular}{cccc}
\hline Gugus fungsi & \multicolumn{3}{c}{ Bilangan gelombang $\left(\mathrm{cm}^{-1}\right)$} \\
\cline { 2 - 4 } & $\begin{array}{c}\text { Asam 2-(4- } \\
\text { (klorometil)benzoiloksi)benzoat }\end{array}$ & $\begin{array}{c}\text { Hasil sintesis } \\
\text { terdahulu }\end{array}$ & Pustaka* $^{*}$ \\
\hline O-H alkohol & 3447,13 & 3447 & $3400-3650$ \\
C=O ester & 1739,39 & 1739 & $1680-1760$ \\
C=C aromatis & 1488 & 1486 & $1475-1600$ \\
C-O ester & 1218 & 1263 & $1210-1320$ \\
\hline
\end{tabular}

* (Robert and David, 2005; Mcmurry \& Simanek, 2007)

Tabel 5. Hasil perhitungan persen hambatan nyeri

\begin{tabular}{ccccccc}
\hline \multirow{2}{*}{$\begin{array}{c}\text { Dosis } \\
(\mathrm{mg} / \mathrm{kgBB})\end{array}$} & \multicolumn{3}{c}{ Rata-rata respon hambatan nyeri } \\
& \multicolumn{3}{c}{$\mathrm{A} \pm \mathrm{SD})$} & $\mathrm{B}$ & \% Hambatan Nyeri \\
& \cline { 2 - 7 } & $\mathrm{B}$ & $\mathrm{C}$ & $\mathrm{A}$ & $\mathrm{B}$ & $\mathrm{C}$ \\
\hline 12,5 & $44,62 \pm 0,53$ & $41,96 \pm 2,56$ & $30,34 \pm 1,54$ & 85,30 & 74,28 & 26,00 \\
25 & $46,35 \pm 1,06$ & $49,50 \pm 1,77$ & $32,35 \pm 0,68$ & 92,48 & 105,58 & 34,34 \\
50 & $54,17 \pm 1,54$ & $50,65 \pm 1,53$ & $35,08 \pm 1,23$ & 124,96 & 110,36 & 45,68 \\
100 & $67,51 \pm 2,89$ & $51,84 \pm 1,64$ & $38,62 \pm 0,71$ & 180,36 & 115,29 & 60,38 \\
200 & $74,17 \pm 2,37$ & $66,43 \pm 1,76$ & $51,56 \pm 1,33$ & 208,01 & 175,87 & 114,12 \\
Kontrol & $24,08 \pm 1,18$ & & & & & \\
negatif & & & & & & \\
\hline
\end{tabular}

Keterangan:

A : 2-(3-(klorometil)benzoiloksi) benzoat

B : 2-(4-(klorometil)benzoiloksi) benzoat

C : asam asetil salisilat

Hasil identifikasi struktur pada beberapa daerah bilangan gelombang $\left(\mathrm{cm}^{-1}\right)$ menunjukkan adanya perbedaan karakteristik dari gugus-gugus fungsi asam 2-(3-(klorometil)benzoiloksi) benzoat dan asam salisilat. Pada asam 2-(3(klorometi)benzoiloksi)benzoat terlihat gugus $\mathrm{O}-\mathrm{H}$ fenolat pada panjang gelombang sekitar $3200 \mathrm{~cm}^{-}$ ${ }^{1}$ telah hilang jika dibandingkan dengan asam salisilat. Hal ini dapat diperkuat dengan adanya gugus $\mathrm{C}=\mathrm{O}$ ester pada panjang gelombang 1695.94 $\mathrm{cm}^{-1}$. Jika dibandingkan dengan senyawa terdahulu yang sudah disintesis, nampak bahwa daerah sidik jari senyawa hasil sintesis dan senyawa terdahulu sama. Karenanya, dapat disimpulkan bahwa senyawa 2-(3-(klorometil)benzoiloksi) benzoat sudah terbentuk. 
Hasil identifikasi struktur pada beberapa daerah bilangan gelombang $\left(\mathrm{cm}^{-1}\right)$ menunjukkan adanya perbedaan karakteristik dari gugus-gugus fungsi asam 2-(4-(klorometil)benzoiloksi) benzoat dan asam salisilat Pada spektrum asam 2-(4(klorometil)benzoiloksi)benzoat tidak terlihat spektrum $\mathrm{OH}$ fenolat pada panjang gelombang sekitar $3200 \mathrm{~cm}^{-1}$. Hal ini diperkuat dengan adanya gugus $\mathrm{C}=\mathrm{O}$ ester pada panjang gelombang $1739,39 \mathrm{~cm}^{-1}$. Jika dibandingkan dengan senyawa terdahulu yang sudah disintesis, nampak bahwa daerah sidik jari senyawa hasil sintesis dan senyawa terdahulu sama. Karenanya, dapat disimpulkan bahwa senyawa 2-(4-(klorometil)benzoiloksi) benzoat sudah terbentuk.

Pada Tabel 5 tersaji hasil uji aktivitas analgesik yang menampilkan rerata waktu respon nyeri kedua senyawa dan persentase hambatan nyeri yang dihasilkan. Kedua senyawa menunjukkan aktivitas analgesik yang lebih baik dari asam asetilsalisilat. Hal ini sejalan dengan hasil penelitian sebelumnya yang dilakukan pada mencit (Martak dkk., 2009; Pratiwi, 2009). Tingginya aktivitas analgesik kedua senyawa dibandingkan asam asetilsalisilat disebabkan karena sifat lipofil pada kedua senyawa turunan lebih tinggi $(\log \mathrm{P}$ 2-(3-(klorometil) benzoiloksi)benzoat = 3,73; $\log$ P 2-(4-(klorometil) benzoiloksi) benzoate $=3,73 ; \log \mathrm{P}$ asam asetilsalisilat $=1,21$ ), sehingga penembusan membran semakin optimal, dan berujung pada peningkatan jumlah senyawa yang berinteraksi dengan reseptor.

Jika dibandingkan antara senyawa 2-(3(klorometil)benzoiloksi)benzoate dan 2-(4(klorometil)benzoiloksi) benzoate dengan one way ANOVA, nampak bahwa persentase hambatan nyeri senyawa 2-(3-(klorometil)benzoiloksi)benzoat lebih besar dibandingkan senyawa 2-(4(klorometil)benzoiloksi) benzoat. Hal ini disebabkan karena perbedaan posisi meta dan para dapat mempengaruhi sifat elektronik kedua senyawa yang berakibat pada interaksi senyawa dengan reseptor. Senyawa 2-(3(klorometil)benzoiloksi)benzoat $\left(\sigma 3-\mathrm{CH}_{2} \mathrm{Cl}=0,11\right.$ ) sebagai pendorong elektron lebih kuat dibandingkan senyawa 2-(4-(klorometil)benzoiloksi)benzoat ( $\sigma$ 4- $\left.\mathrm{CH}_{2} \mathrm{Cl}=0,12\right)$, akan lebih mudah berinteraksi dengan reseptor analgesik (Siswandono \& Susilowati, 2000).

\section{KESIMPULAN}

Penelitian ini melaporkan bahwa asam 2-(3(klorometil) benzoiloksi)benzoat dan asam 2-(4(klorometil)benzoiloksi)benzoat menghasilkan aktivitas analgesik lebih tinggi dibandingkan asam asetilsalisilat.

\section{UCAPAN TERIMA KASIH}

Terima kasih ditujukan kepada pemerintah Indonesia yang telah mendanai penelitian ini melalui program Hibah Bersaing. Terima kasih disampaikan pula kepada Umi Hanik Sekarwati dan Hanna Yosefa Lolo yang mendukung proses penelitian.

\section{DAFTAR PUSTAKA}

Furst, D.E., \& Munster. T., 2000. Obat-obat Antiinflamasi Nonsteroid, Obat-obat Antireumatik Pemodifikasi-penyakit, Analgesik Nonopioid dan Obat-obat Untuk Pirai, in Katzung B.G. (Ed.), Farmakologi Dasar dan Klinik: Basic dan Clinical Pharmacologi, $8^{\text {th }}$ ed, Salemba Medika, Jakarta, 455, 459-461.

Gunawan S.G., 2009. Farmakologi dan Terapi Edisi 5, Bagian Fakultas Kedokteran Universitas Indonesia, Jakarta, 231-233, 235.

Martak R., Soekardjo, B., Surdijati, S., Caroline and Setyabudi, I., 2009. Synthesis of 4Chloromethylbenzoyl Salicylic Acid and Its Analgesic Activity on Mice (Mus musculus), Poster Presentation in Bandung International Conference on Medicinal Chemistry, School of Pharmacy, Bandung.

McMurry, J., \& Simanek, E., 2007. Fundamentals of Organic Chemistry $6^{\text {th }} \mathrm{ed}$., Examview and Examview pro are Registered Trademarks of FsCreations, Inc., America, 413-417.

Mishra, 2011. Analgesic and Inflammatory Activity of Methanol Extract of Scindapsus officinalis Root in Experimental Animals, Odisha, India.

Natalia, O. Caroline C., Soekardjo B., 2013. Pemodelan Interaksi Turunan Potensial Asam Benzoil Salisilat dengan Reseptor Enzim Siklooksigenase-2, Jurnal Farmasi Sains dan Terapan, 1(1), 19-24.

Pratiwi, D.V., 2009. Sintesis Asam 3klorometilbenzoil Salisilat dan Uji Aktivitas Analgesik pada Mencit (Mus musculus), 
Skripsi Sarjana Farmasi, Universitas Katolik Widya Mandala Surabaya.

Purwanto \& Susilowati, R., 2000. Hubungan struktur-aktivitas obat analgetika, In: Siswandono dan Soekardjo, B., (Eds.), Kimia Medisinal 2, Airlangga University Press, Surabaya, 283, 291-292, 295.

Robert, M.S., Francis, X.W., and David, J.K., 2005. Spectrofotometric Identification of Organic Compounds $7^{\text {th }}$ ed., John Wiley and Sons, Inc. America, 72-101.

Siswandono \& Susilowati, R., 2000. Hubungan kuantitatif struktur-aktivitas, in Siswandono dan Soekardjo, B., (Eds.), Kimia Medisinal 1, Airlangga University Press, Surabaya, 265, 304.

Soekardjo B., Caroline, Widharna R.M., 2011. Uji Toksisitas Akut Penentuan LD $_{50}$ Senyawa Turunan Asam Benzoilsalisilat pada Mencit, LPPM Research Project, Unika Widya Mandala, Surabaya.

Vogel, H.G, 2008. Drug Discovery and Evaluation Pharmacological Assay, $3^{\text {rd }}$ ed. Springerverlag, Berlin, 1010-1014, 1031. 